\title{
Distinct Regulatory Pathways Control Neurofilament Expression and Neurotransmitter Synthesis in Immortalized Serotonergic Neurons
}

\author{
Linda A. White, ${ }^{1}$ Mary J. Eaton, ${ }^{1}$ Marcia C. Castro, ${ }^{1,2}$ K. John Klose, ${ }^{1,3}$ Mordecai Y.-T. Globus, ${ }^{5}$ Gerry Shaw, ${ }^{6}$ \\ and Scott R. Whittemore \\ 'The Miami Project, ${ }^{2}$ Neuroscience Program, Departments of ${ }^{3}$ Neurological Surgery and ${ }^{4}$ Physiology and Biophysics, and \\ ${ }^{5}$ Cerebrovascular Disease Research Center, Department of Neurology, University of Miami School of Medicine, Miami, \\ Florida 33136, and ${ }^{6}$ Department of Neuroscience, University of Florida, Gainesville, Florida 32610
}

Following infection of dissociated embryonic day 13 rat medullary raphe cells with a retrovirus encoding the temperaturesensitive mutant of SV40 large T-antigen (T-ag), a neuronal cell line, RN46A, was cloned by serial dilution. At $33^{\circ} \mathrm{C}, \mathrm{RN} 46 \mathrm{~A}$ cells express nuclear $\mathrm{T}$-ag immunoreactivity and divide with a doubling time of $9 \mathrm{hr}$. Undifferentiated RN46A cells express low levels of neuron-specific enolase (NSE) and low (NF-L)and medium (NF-M)- but not high (NF-H)-molecular-weight neurofilament proteins. Under differentiation conditions, RN46A cells cease dividing, take on a neuronal morphology, and express enhanced levels of NSE and all three NF proteins. Elevation of intracellular cAMP levels increases neurofilament protein expression, whereas activators of various other intracellular second messenger systems have no effect. Differentiated RN46A cells express low-affinity nerve growth factor (NGF) receptor (p75 ${ }^{\text {NGFA }}$ ) and are immunoreactive using an antibody that recognizes the carboxy-terminal 13 amino acids of all three trk proteins (pan-trk). Both immunoreactivities could be potentiated by treatment with brainderived neurotrophic factor (BDNF), NGF, and adrenocorticotropic hormone, fragment 4-10 $\left(\mathrm{ACTH}_{4-10}\right)$. Differentiated RN46A cells express low levels of tryptophan hydroxylase (TPH) immunoreactivity, which could be enhanced by treatment with $\mathrm{ACTH}_{4-10}, \mathrm{BDNF}$, or NGF. Low levels of serotonin immunoreactivity are detected in differentiated RN46A cells, and this was potentiated by differentiating RN46A cells with BDNF for $8 \mathrm{~d}$ and $40 \mathrm{~mm} \mathrm{KCl}$ for days 4-8. HPLC analysis confirmed these immunohistochemical data. RN46A cells should prove useful to elucidate intracellular mechanisms that control neurofilament assembly and 5-HT expression in differentiating raphe neurons.

\footnotetext{
Received Feb. 11, 1994; revised Apr. 28, 1994; accepted May 5, 1994.

We thank Efrain Azmitia for helpful discussions during the course of this work Vicky Holets for her assistance with the image analysis, Rob Camarena and Maile Abalia for their photographic expertise, Winston Walters and Elena Martinez for excellent technical assistance, and Richard Bunge and Patricia Whittaker-Azmitia for their critical comments on the manuscript. We are grateful to the following investigators who provided antibody, growth factor, chemical, or plasmid reagents essential to the successful completion of this project: Judith Abraham, Efrain Azmitia, Richard Cotton, Maria Hadjiconstantinou-Neff, Edith Hendley, Michael Jaye, Eugene Johnson Jr., David Kaplan, Ronald Lindsay, Ronald McKay, William Mobley, and Norton Neff. This work was supported by The Miami Project to Cure Paralysis, General Reinsurance, The National Drive to Cure Paralysis NS26887 (S.R.W.), and NS22695 (G.S.).

Correspondence should be addressed to Scott R. Whittemore, The Miami Project, University of Miami School of Medicine, 1600 NW 10th Avenue (R-48), Miami, FL 33136.
}

Copyright (C) 1994 Society for Neuroscience $0270-6474 / 94 / 146744-10 \$ 05.00 / 0$
[Key words: neuronal differentiation, protein kinase A, intermediate filaments, tryptophan hydroxylase, neurotrophins, depolarization, 5-HT]

Much of our understanding of the molecular mechanisms that control the development and regenerative capacity of neurons in both the CNS and PNS derives from in vitro studies using neuronal cell lines. However, these are transformed cell lines of peripheral or unknown cellular origin, which often only partially express specific physiological properties of primary CNS neurons. Recent approaches have enabled the proliferation of neuronal cell populations or the development of neuronal cell lines from CNS neuroepithelial precursors or specific postmitotic neurons.

Expansion of CNS stem cells has enabled isolation of populations of dividing CNS neuronal precursors (Reynolds and Weiss, 1992; Reynolds et al., 1992; Ray et al., 1993). As these populations contain both neuronal and non-neuronal precursors, they should prove useful to delineate factors that regulate cell lineage decisions. Neuronal cell lines have also been developed from transgenic mice in which ncuronal specific promoters drive viral oncogenes (Hammang et al., 1990; Mellon et al., 1990; Largent et al., 1993; Suri et al., 1993). This approach allows targeted immortalization of specific neuronal populations, and they have been utilized in studies to determine the regulation of neurohormonal release (Martinez de la Escalera et al., 1992a,b) and to ameliorate genetic deficits in vivo (Miller et al., 1993). Somatic cell hybrids of primary CNS neurons fused to an immortalized neuronal cell line have generated cell lines that retain many properties of primary CNS neurons (Hammond et al., 1986; Lee et al., 1990; Wood et al., 1990; Choi et al., 1991; Blusztajn et al., 1992; Cashman et al., 1992; Crawford et al., 1992). Neurotransmitter synthesis has been detected in the majority of these cell lines, indicating the relatively mature neuronal phenotype that these cells can attain in vitro. However, these cell lines are tumorigenic and cannot be used in transplantation experiments.

Retroviral transduction of CNS neuroepithelial precursors with constructs encoding various oncogenes has been used to isolate neuronal cell lines (DeVitry et al., 1974; Pessac et al., 1983; Casalbore et al., 1987; Bartlett et al., 1988; Frederiksen et al., 1988; Haltmeier and Rohrer, 1990; Ryder et al., 1990; Renfranz et al., 1991; Bernard et al., 1992; Giordano et al., 1993; Whittemore and White, 1993). Some investigators utilized regulated transforming proteins, such as temperature-sensitive mutants 
of SV40 large T-antigen (Frederiksen et al., 1988; Renfranz et al., 1991; Giordano et al., 1993; Whittemore and White, 1993) or Rous sarcoma virus (Pessac et al., 1983). The advantage of these conditionally immortalized cell lines is that after shifting to nonpermissive temperature, the cells are no longer under the mitotic drive of the oncogene. In principal, these cell lines will constitutively differentiate in the direction they were headed at the time of infection.

Many of these CNS cell lines are pluripotent and can adopt neuronal or glial phenotypes (Bartlett et al., 1988; Frederiksen et al., 1988; Evrard et al., 1990; Ryder et al., 1990; Renfranz et al., 1991; Bernard et al., 1992). Others are neuronally restricted yct retain a remarkable plasticity to respond to environmental signals both in vitro (Whittemore and White, 1993) and in vivo (Onifer et al., 1993b). However, neurotransmitter synthesis has not been documented in these cell lines. Here, we describe the temperature-sensitive neuronal cell line RN46A and delineate distinct intracellular pathways that control neurofilament expression and 5-HT synthesis.

\section{Materials and Methods}

Chemicals. Primary antisera against the indicated antigens were obtained from the following sources: large T-antigen (hybridoma PB101, clone 412), American Type Culture Collection (Rockville, MD); lowaffinity nerve growth factor (NGF) receptor (IgG 192, p75 NGFR), Eugene Johnson Jr., Washington University; pan-trk (Ab 203), David Kaplan, Frederick Cancer Research and Development Center (Frederick, MD); rabbit polyclonal antibody to rat NSE, Polysciences, Inc. (Warrington, PA); serotonin, Incstar (Stillwater, MN); rat tryptophan hydroxylase (TPH), Efrain Azmitia, New York University (WOH 66), and R. G. H. Cotton, Murdock Institute, Victoria, Australia (PH8); aromatic amino acid decarboxylase (AAAD), N. H. Neff and M. HadjiconstantinouNeff, Ohio State University. Antibodies to low (NF-L)-, medium (NF$\mathrm{M}$ )-, and high (NF-H)-molecular-weight neurofilament proteins (DA-2, $R 9$, and R 14, respectively) were developed as previously described (Harris et al., 1991) and are commercially available from Chemicon. The following compounds were generously provided by the indicated investigators: acidic fibroblast growth factor (FGF-1), Michael Jaye, RhonePoulenc, Rorer Pharmaceuticals, Inc. (Collegeville, PA); basic FGF (FGF2), Judith Abraham, Scios, Inc.; NGF, William C. Mobley, University of California, San Francisco; brain-derived neurotrophic factor(BDNF), ciliary neurotrophic factor (CNTF), neurotrophin-3 (NT-3), and NT4/5, Ronald Lindsay, Regeneron, Pharmaceuticals, Inc. (Tarrytown, NY); fluoxetine (Eli Lilly), Edith D. Hendley, University of Vermont. The retroviral producer line psi2tsA58-4 was furnished by Ronald McKay, NIH. Optimem medium (for hybridomas), CNS medium (Kawamoto and Barrett, 1986), and Geneticin (G418) were obtained from GIBCO (Grand Island, NY), and all other powdered media, attachment factors and chemicals were purchased from Sigma Chemical (St. Louis, MO). Bovine serum albumin was obtained from Sigma and Calbiochem (La Jolla, CA), fetal bovine serum (FBS) from Hyclone (Logan, UT), and tissue culture plasticware from various commercial suppliers.

Isolation of the RN46A cell line. Medullary raphe nucleus was discretely dissected from embryonic day 13 Sprague-Dawley rats (Charles River Laboratories, Wilmington, MA). Preparation of cell suspensions and infection with retrovirus were done as previously described (Whittemore and White, 1993). The resulting G418-resistant colonies were isolated and expanded in CNS medium, 10\% FBS, $250 \mu \mathrm{g} / \mathrm{ml} \mathrm{G418.}$ The cell line RN46 was subcloned by limiting dilution to produce the clonal line RN46A. Southern blot analysis confirmed that the cell line was clonal and indicated a single viral integration site (data not shown).

Cell culture. At permissive temperature $\left(33^{\circ} \mathrm{C}\right)$, cells were grown in CNS, $10 \%$ FBS, $250 \mu \mathrm{g} / \mathrm{ml} \mathrm{G418}$. If the cells were to be subsequently differentiated, they were seeded on collagen/fibronectin $\left(100 \mu \mathrm{g} / \mathrm{cm}^{2}\right.$ airdried type I rat tail collagen followed by $1 \mu \mathrm{g} / \mathrm{cm}^{2}$ fibronectin). No apparent differences were seen between RN46A cells grown at $33^{\circ} \mathrm{C}$ on either untreated tissue culture plastic or the collagen/fibronectin substrate. To differentiate RN46A cells, $75 \%$ confluent cells were shifted to $39^{\circ} \mathrm{C}$ (nonpermissive temperature) and the medium changed to $50 \%$ DMEM, 50\% Ham's F12 (D/F) containing 1\%(w/v) bovine serum albumin (BSA) and serum-free medium components modified from Bottenstein and Sato (1979). These components were $1 \mu \mathrm{g} / \mathrm{ml}$ bovine transferrin, $5 \mu \mathrm{g} / \mathrm{ml}$ bovine insulin, $100 \mathrm{~nm}$ putrescine, and $20 \mathrm{~nm}$ progesterone. For most experiments, the RN46A cells were differentiated for $8 \mathrm{~d}$. For the experiments quantifying the expression of $\mathrm{p} 75^{\mathrm{NGFR}}$, TPH, AAAD, and 5-HT immunoreactivities, RN46A cells were grown on eight-chamber Nunc Lab-Tek slides coated as described above.

Immunohistochemistry. NF, glial fibrillary acidic protein (GFAP), galactocerebroside ( $\mathrm{Gal} \mathrm{C}$ ), NSE, and p $75^{\mathrm{NGFR}}$ immunoreactivities were determined as described previously (Sweetnam et al., 1991; Whittemore and White, 1993). For T-ag immunoreactivity, the cells were fixed with $4 \%$ paraformaldehyde (PF) in $0.01 \mathrm{M}$ phosphate buffer (PB), rinsed three times with $\mathrm{PB}$, and incubatcd with $0.1 \%$ Triton $\mathrm{X}-100$. Conditioncd medium from the hybridoma (PB101, clone 412) was used undiluted. After three rinses with $\mathrm{PB}$, fluorescein-labeled goat anti-mouse $\mathrm{IgG}$ (Cappel-Organon Teknika, Malvern, PA) was added. The resulting fluorescence was observed and photographed with a Zeiss IM inverted microscope. For pan-trk immunoreactivity, the cells were fixed with a modified Zamboni's fixative (Holets et al., 1988) containing $1 \%$ glutaraldehyde. For AAAD immunoreactivity, the cells were fixed in $4 \%$ PF in $0.01 \mathrm{M} \mathrm{PB}$; for TPH immunoreactivity, RN46A cells were fixed with $4 \%$ paraformaldehyde, $2 \%$ glutaraldehyde in $0.01 \mathrm{M} \mathrm{PB}$; for serotonin immunoreactivity, the cells were fixed with modified Zamboni's fixative. After fixation, the monolayers were rinsed three times with $\mathrm{PB}$, incubated with $0.1 \%$ Triton $\mathrm{X}-100$, and incubated with pan-trk, TPH, or serotonin antibodies, respectively. The cells were then incubated with the appropriate secondary antibody labeled with avidin-biotin using the Vectastain $\mathrm{ABC}$ method according to the manufacturer's directions (Vector Laboratories, Burlingame, CA). These experiments were photographed with a Zeiss Axiophot microscope.

Effect of pharmacological agents on $N F-M$ expression. Pharmacological agents were added to differentiating RN46A cells after $4 \mathrm{~d}$ at nonpermissive temperature. The rationale for this treatment paradigm was that preliminary studies had shown that these agents were ineffective if used before the cells had grown for at least $4 \mathrm{~d}$ under differentiating conditions. The cells were treated with the agents for $3 \mathrm{~d}$, at which time they were fixed and assessed for NF-M immunoreactivity. The following compounds were added at the concentrations indicated: $10 \mu \mathrm{M}$ dibutyryl cyclic AMP (dbcAMP); NGF, FGF-1, FGF-2 at $25 \mathrm{ng} / \mathrm{ml} ; 10 \mathrm{nM}$ phorbol 12-myristate 13-acetate (PMA); $5 \mathrm{U} / \mathrm{ml}$ granulocyte-macrophage colony-stimulating factor (GM-CSF); $100 \mathrm{nM}$ calcium ionophore A23187; and $10 \mu \mathrm{M}$ retinoic acid. These concentrations were chosen based on effective ranges cited in the literature. Untreated cells served as controls. Each experiment was run in duplicate with a total of four experiments. Upon completion of immunostaining, a random field from each of the duplicate wells was photographed and the number of positive and negative cells counted by an observer who was unaware of which conditions were being quantified. The percentage of NF-M-positive cells was subsequently calculated and the overall statistical significance was determined as described below.

Effect of the time of initiation and duration of forskolin treatment on $N F-L, N F-M$, and $N F-H$ expression. Forskolin $(1 \mu \mathbf{M})$ was added to RN46A cells for the following intervals indicated by days after shift to differentiating conditions: untreated, days $4-8,5-8,6-8,7-8,5-6,5-$ 7 , and days 6-7. On day 8, the cells were fixed and analyzed for NF-L, NF-M, and NF-H immunoreactivities. Random fields from four separate experiments were photographed and coded, and the percentage of NF-positive cells counted by an observer who was unaware of which conditions were being quantified. After breaking the code, the statistical significance of the resultant data was evaluated as described below.

Effects of pharmacological agents on $p 75^{N G F R}$, pan-trk, $A A A D$, and TPH expression. After $4 \mathrm{~d}$ under differentiating conditions, RN46A cells were left untreated or treated for 4 additional days with the following agents: $10 \mathrm{~nm} \mathrm{ACTH}_{4-10}$ (Met-Glu-His-Phe-Arg-Trp-Gly); 0.1 nM aldosterone; $1 \mathrm{nM}$ dexamethasone; $1 \mu \mathrm{M}$ forskolin; $1 \mathrm{U} / \mathrm{ml}$ GMCSF; $0.1 \mathrm{~nm}$ corticosterone; $0.1 \%$ rat serum; BDNF, CNTF, NT-3, NT4/5, epidermal cell growth factor (EGF), FGF-1, and FGF-2 were used at $25 \mathrm{ng} / \mathrm{ml}$. After $8 \mathrm{~d}$, the RN46A cells were qualitatively evaluated for $\mathrm{p} 75^{\mathrm{NGFR}}$, pan-trk, AAAD, or TPII immunoreactivities.

Effect of $B D N F$ and $\mathrm{KCl}$ on TPH and serotonin expression. To examine whether there is an interaction between partial depolarization and neurotrophins on the enhancement of the serotonergic phenotype, RN46A cells were differentiated for $8 \mathrm{~d}$ at $39^{\circ} \mathrm{C}$ in the absence of effectors (media), for $8 \mathrm{~d}$ in medium containing $50 \mathrm{ng} / \mathrm{ml} \mathrm{BDNF}$ (BDNF), for 8 $\mathrm{d}$ in medium containing $50 \mathrm{ng} / \mathrm{ml} \mathrm{BDNF}$ to which $40 \mathrm{~mm} \mathrm{KCl}$ was added during the last $4 \mathrm{~d}$ in culture $(\mathrm{BDNF} / \mathrm{KCl})$, for $8 \mathrm{~d}$ in medium 
Figure 1. Characterization of RN46A cells. RN46A cells were grown under proliferation $\left(33^{\circ} \mathrm{C}\right)(A-C)$ or differentiation $\left(39^{\circ} \mathrm{C}\right)(D-F)$ conditions. Cells are shown under phase-contrast optics $(A, D)$ or following immunohistochemical staining for SV40 large T-antigen $(B, E)$ or neuron-specific enolase $(C, F)$. Scale bar, $50 \mu \mathrm{m}$.
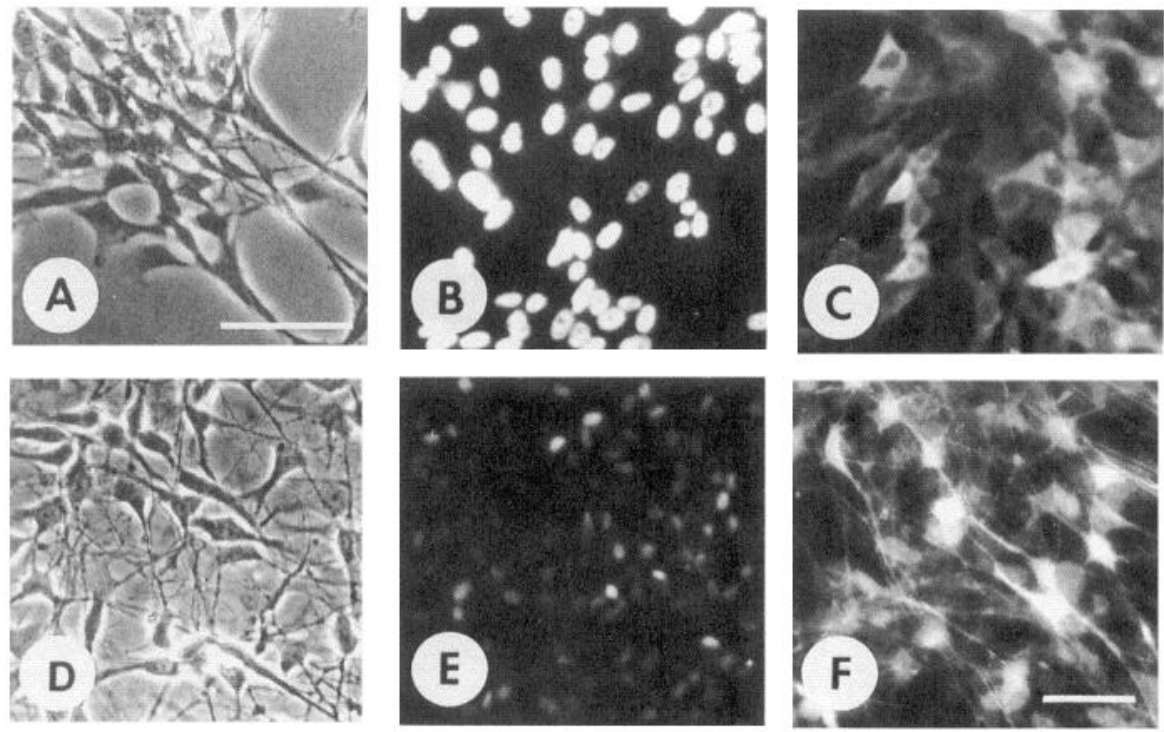

\section{\% NF-M positive}

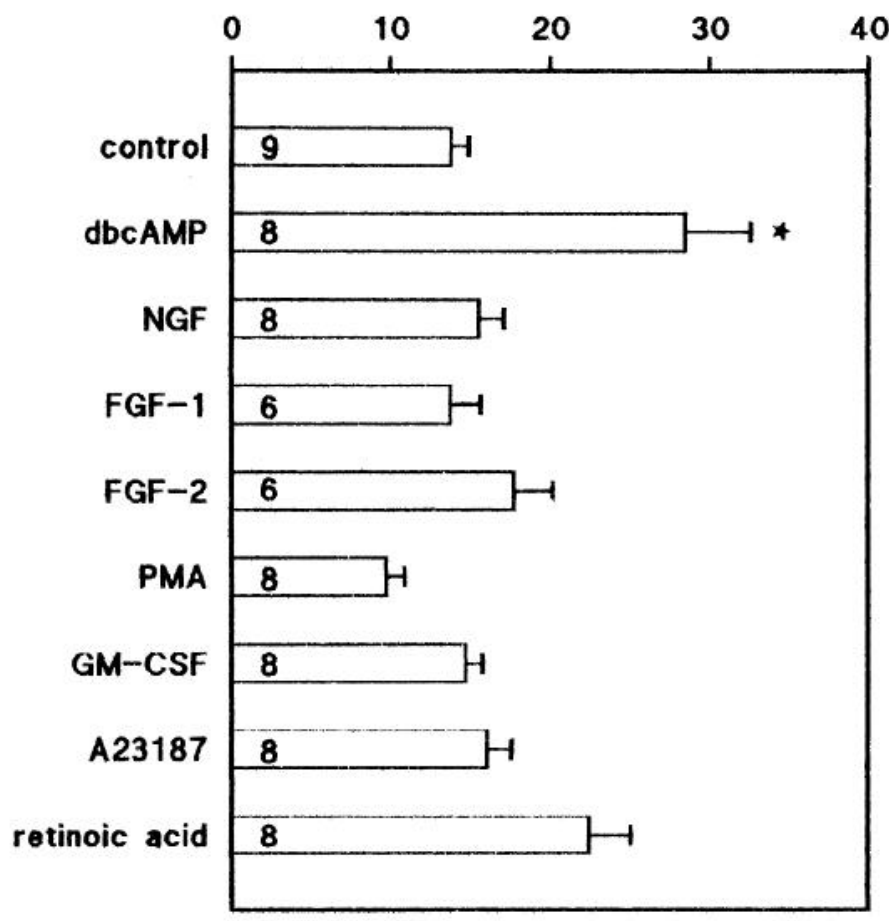

Figure 2. Effect of pharmacological agents on NF-M expression. Pharmacological agents were added to differentiating RN46A cells after $4 \mathrm{~d}$ at $39^{\circ} \mathrm{C}$. The cells were treated for $3 \mathrm{~d}$, at which time they were fixed and assessed for NF-M immunoreactivity. A random field from each of duplicate wells was photographed and the number of positive and negative cells counted. Control cells were untreated. $d b c A M P, 10 \mu \mathrm{M}$ dibutyryl cyclic AMP; $N G F, 25 \mathrm{ng} / \mathrm{ml}$ nerve growth factor; $F G F-1,25$ $\mathrm{ng} / \mathrm{ml}$ acidic fibroblast growth factor; $F G F-2,25 \mathrm{ng} / \mathrm{ml}$ basic fibroblast growth factor; $P M A, 1 \mathrm{~nm}$ phorbol 12-myristate 13-acetate; GM-CSF, $5 \mathrm{U} / \mathrm{ml}$ granulocyte-macrophage colony-stimulating factor. $A 23187$ and retinoic acid were used at $100 \mathrm{~nm}$ and $10 \mu \mathrm{M}$, respectively. Data represent the mean \pm SEM of the number of independent experiments indicated in the respective bars. Only the effect of dbcAMP was significant [overal ANOVA: $F(8,60)=6.87, p<0.001$; unequal $N$ LSD post hoc test for dbcAMP: $p<0.001$ ]. containing $40 \mathrm{~mm} \mathrm{KCl}(\mathrm{KCl})$, or for $8 \mathrm{~d}$ in medium containing $40 \mathrm{~mm}$ $\mathrm{KCl}$ to which $50 \mathrm{ng} / \mathrm{ml}$ BDNF was added during the last $4 \mathrm{~d}$ in culture $(\mathrm{KCl} / \mathrm{BDNF})$. The medium and any additional components were replaced every second day. On day 8 , the cells were rinsed and incubated for $60 \mathrm{~min}$ with $10 \mu \mathrm{M}$ L-tryptophan and $30 \mathrm{~min}$ with $10 \mu \mathrm{M}$ each clorgyline and fluoxetine, and the expression of TPH and serotonin was immunohistochemically assessed. For TPH, a fluorescein-labeled secondary antibody was used, and for serotonin, an avidin-biotin-peroxidase reporter was used to visualize immunoreactivity.

To quantify the expression of TPH and 5-HT under these various conditions, images of the stained cells were captured on video with IMAGE 1 software (Universal Imaging Corp., West Chester, PA) and sorted by staining intensity into one of four groups. The total numerical density, 255 pixels, was divided into four ranges of density ( $0-64$ pixels, none or minimal staining intensity; $65-129$ pixels, low staining intensity; $130-195$ pixels, moderate staining intensity; and 196-255 pixels, maximal staining intensity), each range corresponding to a pseudocolor. This analysis allows quantitation of the number of cells expressing variable levels of immunoreactivities and reflects TPH or 5-HT synthesis in the entire population of differentiating RN46A cells. In each field of cells, the number of cells corresponding to each pseudocolor group was counted. Background was initially subtracted using a slide identically stained with nonimmune IgGs and the background subtraction subroutine program on IMAGE 1 software. All slides, both bright field and fluorescent, were analyzed under identical lighting conditions. The antigens that were detected with the $\mathrm{ABC}$ secondary antibodies were processed with identical development times with the peroxidase substrate. For each condition, 500-1000 cells were counted from at least eight random fields from each of three independent experiments (1500-3000 total cells). Statistical significance was determined as described below.

HPLC measurement of 5-HT levels. RN46A cells were differentiated in six-well Costar tissue culture plates with no additions (media), BDNF, or $\mathrm{BDNF} / \mathrm{KCl}$ as described above. One hour prior to harvesting the cells, they were incubated with $10 \mu \mathrm{M}$ L-tryptophan, and $30 \mathrm{~min}$ later fluoxetine and clorgyline were added to $10 \mu \mathrm{M}$. After incubation for an additional $30 \mathrm{~min}$, cells were gently scraped off the tissue culture plate in $2 \mathrm{ml}$ of PBS and a $100 \mu \mathrm{l}$ was aliquot removed for protein determination by the Micro BCA Protein Assay (Pierce, Rockford, IL). The remainder of the cells were pelleted at $4^{\circ} \mathrm{C}$. Following removal of the supernatant, HPLC buffer ( $0.1 \mathrm{~m}$ acetic acid in $2 \% \mathrm{EtOH})$ was added to bring the protein concentration to $2 \mathrm{mg} / \mathrm{ml}$. Samples were sonicated, centrifuged at $13,000 \times g$ for $15 \mathrm{~min}$ at $4^{\circ} \mathrm{C}$, and $50 \mu \mathrm{l}$ aliquots of the supernatants snap frozen in liquid nitrogen for subsequent HPLC analysis. Concentrations of serotonin were determined by reverse-phase isocratic liquid chromatography with electrochemical detection, as described previously (Globus et al., 1992).

Statistical analysis. The statistical significance of all quantitative data was determined with a multivariate analysis of variance (MANOVA). 

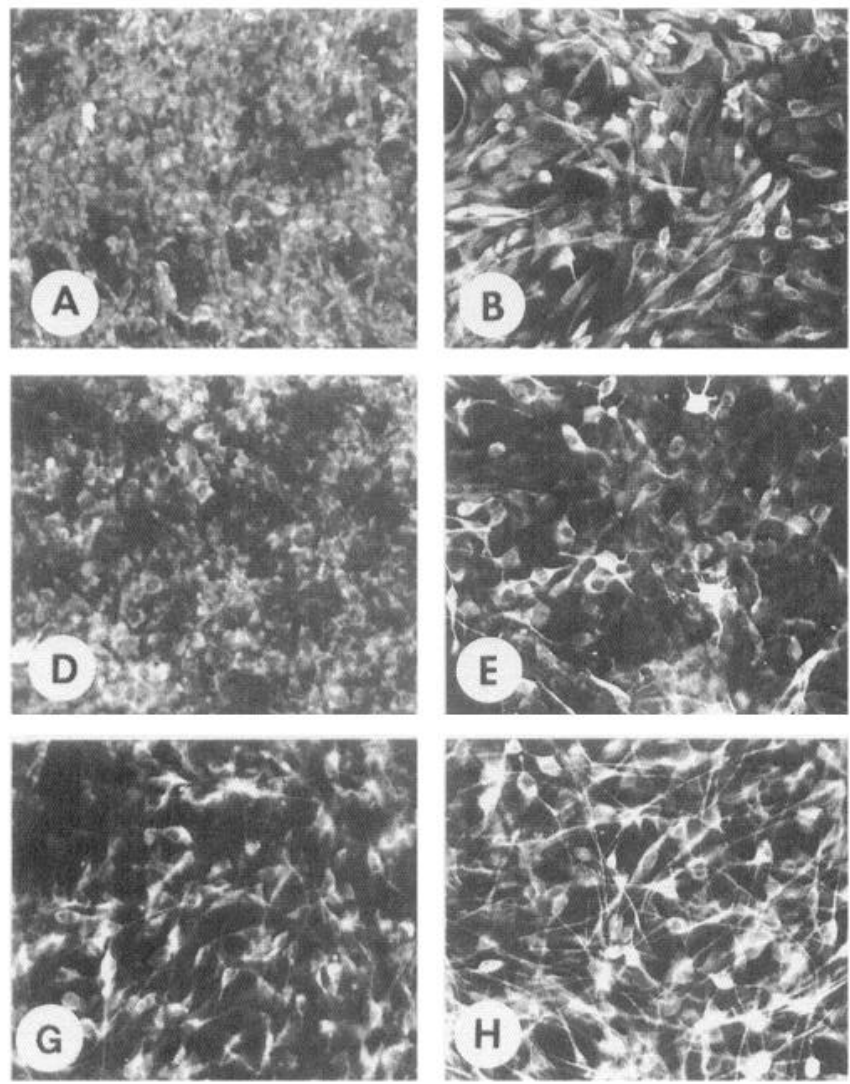

Comparisons of differences between individual means were tested using the Tukey honest significant difference (HSD) method or the unequal $N$ least significant difference (LSD) test. All of the analyses were performed with a commercially available software package (STATISTICA, Statsoft, 1990).

\section{Results}

Morphology of RN46A cells and the expression of cell-specific antigens

At $33^{\circ} \mathrm{C}$, RN46A cells divide with a doubling time of $9 \mathrm{hr}$, have a fibroblast-like morphology (Fig. $1 A$ ), and express nuclear T-ag immunoreactivity (Fig. $1 B$ ) and low levels of NSE (Fig. 1C). Undifferentiated RN46A cells were immunopositive for NF-L and NF-M, although NF-H immunoreactivity could not be detected. The NF-L and NF-M immunoreactivities were located perinuclearly in the cytoplasm (see Fig. $3 A-C$ ). When RN46A cells are shifted to differentiating conditions, the cells cease dividing and appear neuronal, extending long, sometimes multipolar processes (Fig. 1D). Nuclear T-ag immunoreactivity is absent or greatly reduced (Fig. $1 E$ ), while NSE immunoreactivity is markedly increased (Fig. $1 F$ ). Subpopulations of differentiated RN46A cells are immunoreactive for neurofilament proteins, although few NF-H-positive cells were seen (see Fig. $3 D-F)$. Under no conditions were the glial antigens GFAP or GalC detected in RN46A cells (data not shown).

\section{Dibutyryl CAMP enhances $N F-M$ expression in differentiating $R N 46 A$ cells}

A number of pharmacological agents that activate various intracellular second messenger systems were tested for their effects on RN46A cell differentiation. As an initial qualitative screen, the expression of NF-M immunoreactivity was used as an index
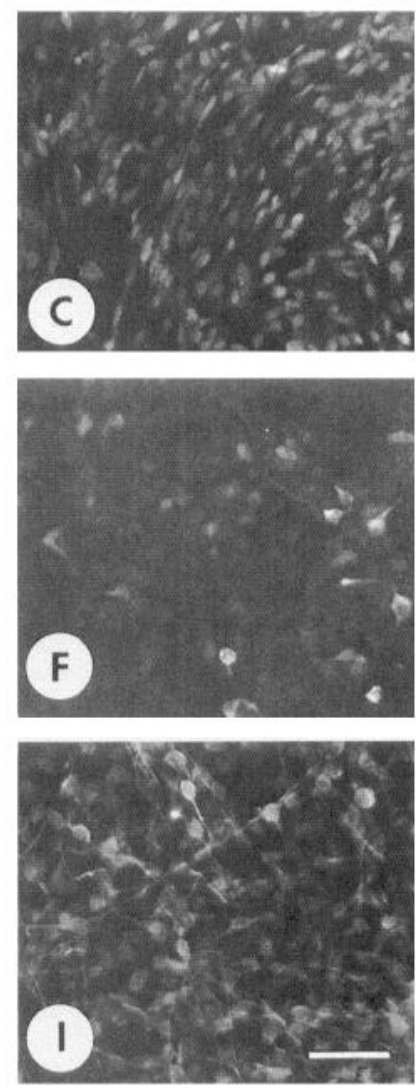

Figure 3. NF-L, NF-M, and NF-H expression in RN46A cells. Undifferentiated RN46A cells $\left(33^{\circ} \mathrm{C}\right)(A-C)$ or RN46A cells differentiated for $8 \mathrm{~d}\left(3^{\circ} \mathrm{C}\right)$ in the absence $(D-F)$ or presence $(G-I)$ of $1 \mu \mathrm{M}$ forskolin for days 4-8 were immunohistochemically evaluated for the expression of NF-L $(A, D, G)$, NF-M $(B, E, H)$, and NF-H $(C, F, I)$. Scale bar, $50 \mu \mathrm{m}$. of neuronal differentiation, both to allow assessment of enhanced NF-M synthesis and to delineate the potential induction of neuritic outgrowth and/or branching. NF-M appears early in neuronal development and its expression is a sensitive indicator of the initial progression of neuronal differentiation. Treatment with dbcAMP significantly enhanced $(2.1$-fold, $p<0.001)$ the number of differentiated RN46A cells that expressed NF-M (Fig. 2). NGF, FGF-1, FGF-2, PMA, GM-CSF, A23187, and retinoic acid were all ineffective in increasing the number of NF-M positive RN46A cells.

\section{Temporal regulation of $N F$ expression by forskolin in differentiating $R N 46 \mathrm{~A}$ cells}

Initial results demonstrated that dbcAMP and forskolin treatment resulted in identical induction of NF-M expression in RN46A cells and subsequent studies were undertaken with forskolin. Treatment of RN46A cells with forskolin between days $0-4$ after shifting to differentiating conditions did not enhance NF-M expression (data not shown). However, increasing intracellular cAMP levels between days 4 and 8 of differentiation markedly enhanced NF-M expression (Fig. $3 H$ ) as well as NF-L (Fig. $3 G$ ) and, to a lesser extent, NF-H (Fig. 3I). Therefore, experiments were designed to determine if a critical period of RN46A cell differentiation existed, during which enhanced intracellular cAMP levels would maximally potentiate NF expression and/or assembly. RN46A cells were treated with $1 \mu \mathrm{M}$ forskolin for varying intervals after the shift to differentiating conditions and assessed for the expression of NF-L, NF-M, and NF-H immunoreactivities.

A significant increase, $48 \%$ above control, in the number of NF-L-positive RN46A cells was only seen following addition 


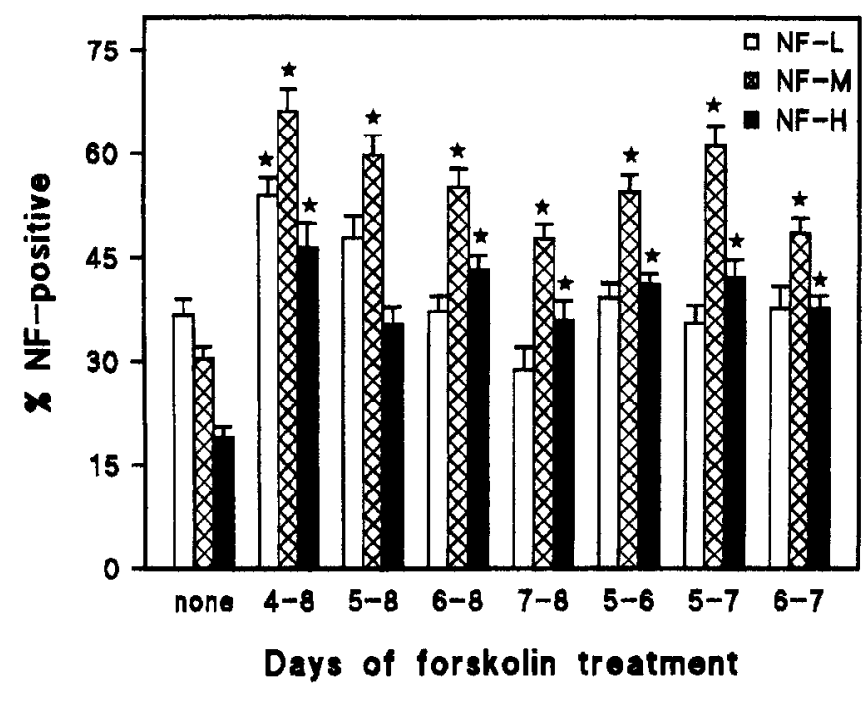

Figure 4. Effect of the time of initiation and the duration of forskolin treatment on NF-L, NF-M, and NF-H expression. Forskolin $(1 \mu \mathrm{M})$ was added to RN46A cells for the intervals indicated by days after shift to nonpermissive temperature $\left(39^{\circ} \mathrm{C}\right)$. On day 8 , the cells were fixed and immunohistochemically assessed for NF-L (open bars), NF-M (crosshatched bars), and NF-H (solid bars) expression. Random fields from four independent experiments were photographed and counted. Data represent the mean \pm SEM of the percentage of NF-positive cells from 14-23 random fields. ANOVA showed that forskolin treatment across all treatment paradigms had a significant effect on neurofilament protein expression $[F(7,416)=25.54, p<0.001]$. Moreover, the differential expression of NF-L, NF-M, and NF-H induced by the various forskolin treatments was highly significant $[F(2,416)=80.96, p<0.001]$. Lastly, the interaction between forskolin induction of the individual NF proteins and the treatment paradigms was also highly significant $[F(14,416)$ $=4.67, p<0.001]$. *, significant differences $(p<0.05)$ of individual treatment groups from control values for each of the neurofilament proteins.

of forskolin on day 4 and maintained between days 4 and 8 (Fig. 4, open bars). Small changes that did not exceed $31 \%$ above control were observed with forskolin treatment at later times, but these differences were not statistically significant. In contrast, forskolin treatment of differentiating RN46A cells for all time periods after day 4 significantly increased the number of NF-M-positive cells (Fig. 4, crosshatched bars). Maximal effects were seen between days 4-8 (118.1\% above control), but even $24 \mathrm{hr}$ treatment on days $6-7(60.0 \%)$ or $7-8(57.2 \%)$ also significantly enhanced NF-M levels. The number of NF-H-positive RN46A cells was also increased by forskolin treatment (Fig. 4 , solid bars), with maximal effects seen following differentiation in forskolin for days $4-8$ (144.4\% above control). Similar to results seen with NF-M, most of the treatment paradigms were effective, the exceptions being days 5-8. However, as this value was $85.6 \%$ above control and approached statistical significance $(p=0.06)$, a larger sample size may have given significant differences. Overall, forskolin treatment resulted in a greater percentage of total NF-M-positive RN46A cells compared to the number of either NF-L- or NF-H-positive cells $[F(7,416)$ $=25.54, p<0.001]$.

Interestingly, forskolin not only increases the expression of the neurofilament proteins but also affected NF distribution (Fig. 3). Differentiated RN46A cells exhibit a predominantly perinuclear localization of NF-L and NF-M immunoreactivities, although NF-M immunoreactivity can readily be detected in the proximal end of the neurites (Fig. $3 D, E$ ). Treatment with
Table 1. Effects of pharmacological agents of the expression of p75 ${ }^{\text {NGFr, }}$, pan-trk, AAAD, and TPH immunoreactivities

\begin{tabular}{|c|c|c|c|c|}
\hline Effectors & p $75^{\text {NGFR }}$ & - trk & AAAD & TPH \\
\hline $\mathrm{ACTH}_{4-10}$ & $\uparrow \uparrow$ & $\uparrow \uparrow$ & $\uparrow$ & $\uparrow \uparrow$ \\
\hline Aldosterone & $\mathrm{nc}$ & nt & nt & $\mathrm{nc}$ \\
\hline Dexamethasone & $\mathrm{nc}$ & $\uparrow$ & nc & $\uparrow \uparrow$ \\
\hline Corticosterone & nc & nt & $\mathrm{nt}$ & nc \\
\hline Forskolin & $\uparrow$ & $\mathrm{nt}$ & nt & nc \\
\hline Rat serum & $\uparrow$ & $\uparrow$ & nt & $\uparrow$ \\
\hline BDNF & $\uparrow$ & $\uparrow \uparrow$ & $\uparrow$ & $\uparrow \uparrow$ \\
\hline NGF & $\uparrow \uparrow$ & $\uparrow$ & $\uparrow$ & $\uparrow$ \\
\hline NT3 & nc & nc & nc & nc \\
\hline NT4/5 & nc & nc & nc & $\mathrm{nc}$ \\
\hline CNTF & nc & nc & nc & $\mathrm{nc}$ \\
\hline EGF & $\mathrm{nc}$ & nc & nc & $\mathrm{nc}$ \\
\hline GM-CSF & nc & nc & nc & nc \\
\hline FGF-1 & nc & nc & $\mathrm{nc}$ & nc \\
\hline FGF-2 & $\mathrm{nc}$ & $\mathrm{nc}$ & $\mathrm{nc}$ & nc \\
\hline
\end{tabular}

RN46A cells were differentiated for $4 \mathrm{~d}$, followed by addition of the indicated effectors for an additional $4 \mathrm{~d}$. Cells were subsequently qualitatively evaluated by immunohistochemistry for the expression of low-affinity nerve growth factor receptor (p75 NGFR), pan-trk, aromatic amino acid decarboxylase (AAAD), and tryptophan hydroxylase (TPH). The effectors and their concentrations were as follows: $10 \mathrm{nM} \mathrm{ACTH}_{4-10}, 0.1 \mathrm{nM}$ aldosterone, $1 \mathrm{~nm}$ dexamethasone, $1 \mu \mathrm{M}$ forskolin, 1 $\mathrm{U} / \mathrm{ml}$ GM-CSF, $0.1 \mathrm{~nm}$ corticosterone, $0.1 \%$ rat serum, and BDNF, NGF, CNTF, NT3, NT4, EGF, FGF-1, FGF-2 were all used at $25 \mathrm{ng} / \mathrm{ml}$. nc, no change observed compared to controls; nt, not tested.

$\uparrow \uparrow$, moderate increase compared to controls; $\uparrow$, small increase in the number of immunoreactive cells compared to controls. Identical results were obtained in two to three independent experiments.

forskolin increased the amount of all three NF proteins and led to an intracellular redistribution of these proteins into the cell processes (Fig. 3G,H). This was especially apparent with NF$M$, where forskolin treatment resulted in NF-M expression in nearly all RN46A cclls. Whilc forskolin increased NF-H expression, it did so to a much lower extent than for NF-L and NF-M (compare Fig. $3 I$ with $3 G, H$ ).

\section{Regulation of $p 75^{\text {NGFR }}$, pan-trk, AAAD, and TPH expression}

Initial experiments demonstrated that differentiating RN46A cells expressed p75 ${ }^{\mathrm{NGFR}}$, pan-trk, and AAAD immunoreactivities (data not shown), as well as that for TPH (Fig. $5 A$ ). In attempts to define possible extracellular effectors that might enhance the expression of these proteins and, hence, maximize potential serotonergic properties, a variety of pharmacological agents were tested on differentiating RN46A cells (Table 1). The expression of low- and high-affinity neurotrophin receptors p75 ${ }^{\text {NGFR }}$ and pan-trk, respectively, was potentiated by $\mathrm{ACTH}_{4}$ ${ }_{10}$, BDNF, and NGF. Dexamethasone only slightly enhanced pan-trk expression but did not effect p $75^{\text {NGFR }}$ levels. Interestingly, forskolin only slightly increased $\mathrm{p} 75^{\mathrm{NGFR}}$ but did not increase the number of pan-trk positive cells. One percent rat serum slightly enhanced the levels of both proteins, while aldosterone, cortiçosterone, CNTF, NT-3, NT-4/5, EGF, GMCSF, FGF-1, and FGF-2 were without effect.

$\mathrm{ACTH}_{4-10}, \mathrm{BDNF}$, and NGF also increased the number of RN46A cells that expressed the enzymes necessary for 5-HT synthesis, TPII and AAAD. Dexamethasone increased TPH without affecting AAAD, while rat serum slightly increased TPH immunoreactivity. These results do not reflect increased proliferation as there was no incorporation of 5-bromo-2'-deox- 

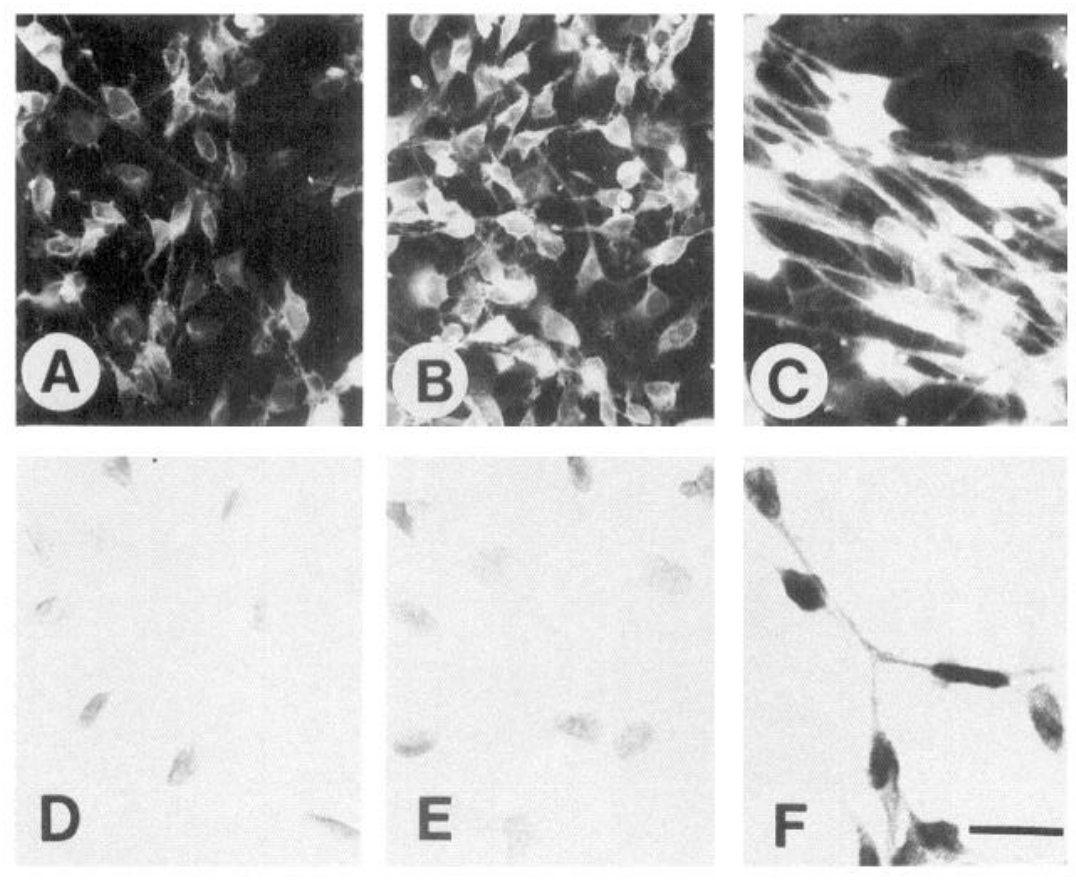

Figure 5. Qualitative assessment of BDNF and $\mathrm{KCl}$ effects on TPH and 5-HT expression. RN46A cells were differentiated for $8 \mathrm{~d}$ in the absence of effectors $(A, D)$, in the presence of 50 $\mathrm{ng} / \mathrm{ml} \mathrm{BDNF}(B, E)$, or the presence of $50 \mathrm{ng} / \mathrm{ml} \mathrm{BDNF}$ in conjunction with 40 mM $\mathrm{KCl}$ for days 4-8 $(C, F)$. RN46A cells were then immunohistochemically evaluated for the expression of tryptophan hydroxylase $(A-C)$ or 5-HT $(D-$ F). Scale bar, $50 \mu \mathrm{m}$.

yuridine (BrdU) under any of these conditions (data not shown). Increasing intracellular cAMP levels with forskolin did not enhance TPH expression. Likewise, aldosterone, corticosterone, NT-3, NT-4/5, EGF, GM-CSF, CNTF, FGF-1, and FGF-2 were all ineffective in increasing the number of AAAD and TPH immunoreactive RN46A cells.

\section{Temporal interaction of $B D N F$ and $\mathrm{KCl}$ in potentiating TPH and 5-HT expression}

The presence of both TPH and AAAD immunoreactivities in a subset of differentiating RN46A cells strongly suggested that RN46A cells were serotonergic. Under basal differentiating conditions, very few RN46A cells were 5 -HT positive (Fig. $5 D$ ), despite readily detected expression of TPH immunoreactivity (Fig. 5A). Differentiating RN46A cells with BDNF markedly enhanced TPH expression (Fig. 5B, Table 1), but did not appear to increase the number of 5-HT-positive cells (Fig. 5E). Previous studies have suggested that growth factors and partial depolarizing conditions can interact to regulate neuronal differentiation (Birren et al., 1992; Rao et al., 1992; Sun et al., 1992). We investigated the potential combined effects of partial depolarizing conditions and BDNF on the serotonergic properties of RN46A cells. RN46A cells differentiated in the presence of BDNF for days 0-8 with concurrent culture in $40 \mathrm{mM} \mathrm{KCl}$ for days 4-8 (BDNF/KCl) showed marked enhancement of both TPH (Fig. 5C) and 5-HT (Fig. 5F) immunoreactivities.

Quantitative image analysis showed that BDNF caused a fourfold $(p<0.02)$ increase in the number of high fluorescence intensity TPH-immunoreactive RN46A cells (Fig. 6A). Differentiating the cells with $\mathrm{BDNF} / \mathrm{KCl}$ shifted the distribution of TPH fluorescence intensities such that sevenfold $(p<0.001)$ more RN46A cells showed high levels of TPH immunoreactivity. $\mathrm{RN} 46 \mathrm{~A}$ cells cultured in $\mathrm{KCl}$ or $\mathrm{KCl} / \mathrm{BDNF}$ did not increase TPH immunoreactivity above control levels. If the RN46A cells were differentiated in $\mathrm{BDNF}, \mathrm{KCl}$, or $\mathrm{KCl} / \mathrm{BDNF}$, no significant differences in the number of high-5-HT-expressing cells were detected from that seen in media alone. Robust increases in 5-HT immunoreactivity (Fig. $6 B$ ) were only seen with BDNF/ $\mathrm{KCl}$, as the population of immunopositive cells was markedly shifted 8.5 -fold $(p<0.001)$ toward high immunoreactive levels. Culturing with $\mathrm{KCl}$ did decrease the number of RN46A cells in the minimal 5-HT-immunoreactive group, irrespective of whether BDNF was present. These data suggest that the low levels of TPH seen in RN46A cells differentiated in the absence of BDNF were being activated by the partial depolarization, resulting in cells with slightly higher levels of 5-HT. However, the number of RN46A cells in the high 5-HT immunoreactivity group was only increased if BDNF treatment was followed by depolarizing conditions.

In addition, differentiating RN46A cells in the presence of $\mathrm{KCl}$ resulted in an altered cellular morphology. The neuritic extensions were much longer and the cell somata more elongate (compare Fig. $5 C, F$ with $5 A, B, D, E$ ). This altered morphology was independent of the increases in TPH and 5-HT immunoreactivities, as it occurred when RN46A cells were differentiated in $\mathrm{KCl}$ or $\mathrm{KCl} / \mathrm{BDNF}$. As noted above, these two latter conditions do not enhance 5-HT immunoreactivity.

Although not directly quantified, none of the pharmacological agents used in the experiments to examine neurofilament or neurotrophin receptor expression or serotonergic properties appeared to decrease RN46A cell survival.

\section{HPLC detection of 5-HT levels}

The quantitative morphological data demonstrating the enhancement of 5-HT synthesis by $\mathrm{BDNF}$ and $\mathrm{KCl}$ were substantiated by measuring 5-HT levels by HPLC (Fig. 7). RN46A cells differentiated in the absence of effectors (media) contained $346.6 \pm 79.9 \mathrm{pmol}$ of $5-\mathrm{HT} / \mathrm{mg}$ protein. RN46A cells differentiated in the presence of BDNF did not increase the levels of 5 -HT. However, differentiation of RN46A cells in BDNF/ KCl increased 5-HT levels 3.4-fold $(p<0.001)$ above that seen in media or BDNF alone. 
Figure 6. Quantitative assessment of BDNF and $\mathrm{KCl}$ effects on TPH and 5-HT expression. RN46A cells were differentiated for $8 \mathrm{~d}$ under the conditions indicated in the code at the bottom of the figure, and described in Materials and Methods. Cells were then immunohistochemically stained for tryptophan hydroxylase $(T P H)(A)$ and serotonin $(5-H T)(B)$. The levels of the respective immunoreactivities in individual cells were quantified by image analysis and sorted into four bins of increasing immunoreactivity from minimal to high as described in Materials and Methods. Data are the mean \pm SEM of $1500-3000$ individual cells for each condition counted from three independent experiments. ANOVA showed that the interaction between treatment groups and labeling intensity groups was highly significant for both TPH $[F(12,292)=22.93, p<0.001]$ and 5-HT $[F(12,292)=67.46, p<$ $0.001]$. Using the unequal $N$ LSD post hoc test to distinguish significance between individual data groups, the highintensity immunoreactivity group was evaluated. *, compared to the high-intensity group, $\mathrm{BDNF} / \mathrm{KCl}$ was statistically different $(p<0.001)$ than all other groups, which did not differ from each other.
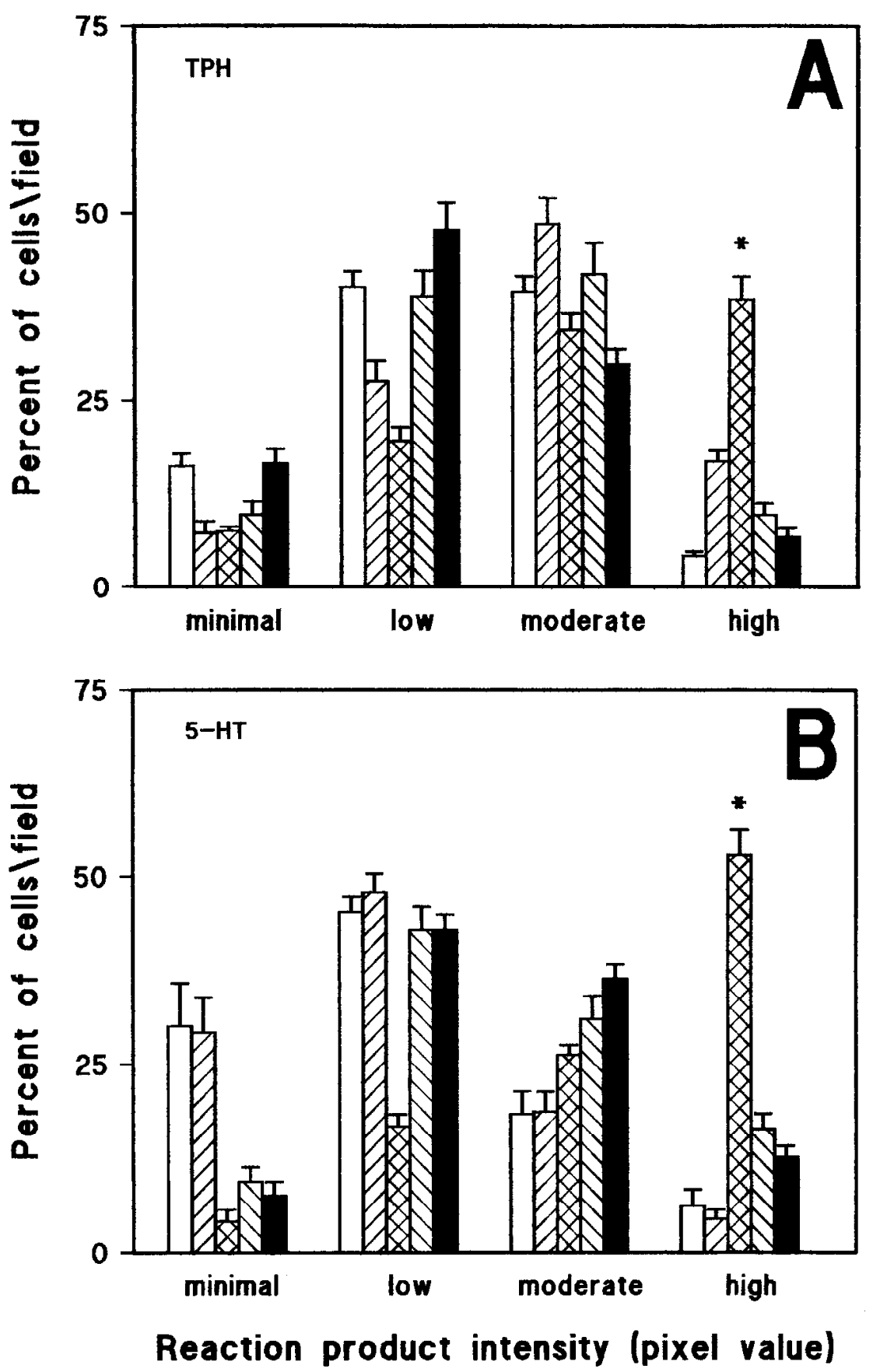

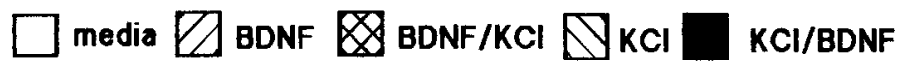

\section{Discussion}

The majority of the neuronal CNS cell lines derived by retroviral transduction are pluripotent, with the potential for neuronal and glial differentiation (Bartlett et al., 1988; Frederiksen et al., 1988; Evrard et al., 1990; Ryder et al., 1990; Renfranz et al., 1991; Bernard et al., 1992). This contrasts with RN46A cells, and the similar raphe-derived RN33B cell line (Whittemore and White, 1993) in which differentiation is constitutive and neuronally restricted. These differences likely reflect the fact that medullary raphe neurogenesis pcaks betwecn E13 and E14 (Lauder and Bloom, 1974), and the neuroepithelial precursors were com- mitted to the neuronal lineage at the time of infection (E12.5). This suggestion is supported by the fact that dividing, undifferentiated RN46A cells synthesize NSE, NF-L, and NF-M. Bipotential cell lines likely arise when very early neurocpithclial precursors or regions undergoing both neurogenesis and gliogenesis are infected.

In the absence of exogenous pharmacological agents, differentiated RN46A cells expressed NSE, NF-L, NF-M, and little $\mathrm{NF}-\mathrm{H}$, as well as vimentin and nestin (data not shown). Vimentin is present early in neuroepithelial cell development, and can coexist with neurofilament proteins as neuronal differentiation initiates. In developing neurons, NF-L and NF-M initially 
appear and later, NF-H is expressed as the neuron matures (Shaw, 1991; Nixon and Shea, 1992). These data would indicate that RN46A cells differentiated in clonal culture are at an early stage of development, and additional effectors are required for more extensive neuronal maturation.

Of the effectors tested, only those that elevated intracellular cAMP levels upregulated neurofilament expression. It is unlikely that the effects of dbcAMP were mediated by the butyrate moiety, as identical results were obtained with forskolin. Moreover, the neurofilament promoters do not contain cAMP-response elements (Elder et al., 1992a,b), indicating that cAMP is not directly activating neurofilament transcription. These data suggest that cAMP secondarily increased cAMP-dependent protein kinase (PKA) activity, which resulted in enhanced neurofilament expression. Activation of other intracellular second messenger systems were ineffective in increasing NF expression. Although not directly quantified, none of these agents, including dbcAMP, markedly altered neurite outgrowth in RN46A cells. Forskolin treatment upregulated NF-M expression in a similarly derived neuronal cell line RN33B (Whittemore and White, 1993), suggesting that this mechanism for induction of neurofilament synthesis and altered distribution of the neurofilaments may be a general one in CNS neurons. The initial qualitative screen for pharmacological agents that enhanced RN46A cell differentiation examined a single parameter (NF-M expression). Activation of other signaling pathways are likely to be involved in different aspects of neuronal differentiation (discussed below).

The expression of all three neurofilament proteins was increased by forskolin treatment, although this was most readily seen with NF-M and, to a lesser extent, NF-L. The fact that few NF-H-positive RN46A cells were observed suggests that activation of PKA is alone insufficient to initiate the mature pattern of NF triplet protein expression. These data are consistent with in vivo results that demonstrated that NF-H expression occurs subsequent to synaptogenesis, likely in response to an as yet unidentified target-derived signal (Shaw and Weber, 1982, 1983; Patcher and Liem, 1984; Carden et al., 1987). In addition to differential temporal expression of the three neurofilament proteins during neuronal differentiation, NF-M and NF-H are also differentially phosphorylated during development (Carden et al., 1987; Nixon and Sihag, 1991; Shaw, 1991). However, we specifically chose neurofilament antibodies that recognized epitopes in the tail domains of NF-M and NF-H that are minimally affected by the phosphorylation state (Harris et al., 1991). This allowed detection of NF-M and NF-H without the complication of differential antigenic recognition of the various phosphoprotein intermediates.

Neurofilament assembly is regulated by a variety of distinct kinase systems. All three neurofilament proteins have multiple phosphorylation sites, with residues in the amino-terminal head domain phosphorylated predominantly by second messengerdependent protein kinases while those in the carboxy-terminal tail domain appear to be mostly second messenger independent (Nixon and Sihag, 1991; Shaw, 1991). PKA-dependent phosphorylation of NF-L monomers in vitro prevents their assembly, and similar phosphorylation of isolated NF-L filaments results in their disassembly (Hisanga et al., 1990; Nakamura et al., 1990). How these in vitro results reflect potential regulatory mechanisms in intact neurons is unclear. Present data with RN46A cells suggest that activation of PKA is a necessary prerequisite for enhanced neurofilament synthesis and assembly of both NF-L and NF-M. Whether this activation of PKA sec-

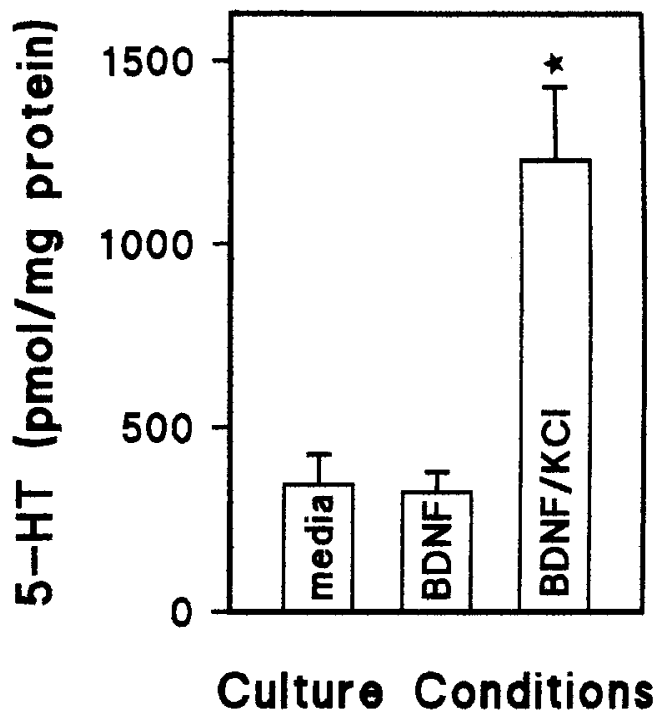

Figure 7. HPLC analysis of 5-HT levels in differentiated RN46A cells. RN46A cells differentiated under the conditions indicated in the respective data bars were assayed by HPLC for the presence of 5-HT. Data represent the mean \pm SEM from 11-15 replicate wells/condition, which derive from three independent experiments. ANOVA indicated that the data were statistically significant $[F(2,23)=13.90, p<0.001]$, and unequal $N L S D$ post hoc test indicated that $\mathrm{BDNF} / \mathrm{KCl}$ was different from all other groups $\left({ }^{*}, p<0.001\right)$.

ondarily results in direct phosphorylation of the neurofilament proteins as an obligate step for increasing expression and altered intracellular distribution is at present unresolved. However, the catalytic subunit of PKA is closely associated with neurofilament proteins, and this interaction is tightly regulated by cAMP (Dosemeci and Pant, 1992). Moreover, both NF-L and NF-M have PKA-dependent phosphorylation sites in the head domain that are heavily phosphorylated in the cell soma and are gradually dephosphorylated as the NFs are transported to the distal axon (Black and Lee, 1988; Sihag and Nixon, 1990, 1991). Thus, present data are consistent with a direct role for PKA-dependent phosphorylation in early intracellular events that regulate NF-L and NF-M synthesis and distribution in RN46A cells.

In contrast, 5-HT synthesis in differentiating RN46A cells is regulated by a different cellular mechanism(s). Both AAAD and TPH immunoreactivities were upregulated by $\mathrm{ACTH}_{4-10}$ and BDNF, and unaffected by PKA activation. $\mathrm{ACTH}_{4-10}$ has been shown previously to potentiate serotonergic function in primary raphe neurons (Azmitia and de Kloet, 1987). Maximal numbers of 5-HT-positive RN46A cells were seen following treatment with $\mathrm{BDNF} / \mathrm{KCl}$. The $\mathrm{HPLC}$ data directly quantifying $5-\mathrm{HT}$ levels confirmed the immunohistochemical data. $\mathrm{BDNF} / \mathrm{KCl}$ treatment had no effect on the expression or distribution of any of the neurofilament proteins (data not shown), despite the elongated neurites observed in RN46A cells grown under partial depolarizing conditions. BDNF actions are mediated through interaction with and subsequent auto-tyrosine phosphorylation of the tyrosine kinase receptor trkB (Chao, 1992). RN46A cells contain immunohistochemically detectable levels of trk protein, as identified with an antibody that specifically recognizes the carboxy-terminal 13 amino acids of all three trk proteins (pantrk Ab 203; Hemstead et al., 1992). While BDNF treatment markedly upregulates pan-trk and TPH expression, NGF also slightly enhanced the levels of these immunoreactivities, sug- 
gesting the potential presence of trkA as well. While beyond the scope of the present report, ongoing studies are addressing which specific trk protein(s) are activated in RN46A cells.

Previous results have shown that TPH can be activated by $\mathrm{Ca}^{2+} /$ calmodulin-dependent protein kinase (CaMK) (BoadleBiber and Phan, 1987; Ehret et al., 1989; Isobe et al., 1991). Moreover, partial depolarization increases 5-HT levels in brainstem slices (Hamon et al., 1979; Boadle-Biber and Phan, 1986). This effect could be mimicked by agents that increase intracellular $\mathrm{Ca}^{2+}$ levels (Boadle-Biber, 1979) and blocked by replacing extracellular $\mathrm{Ca}^{2+}$ with $\mathrm{Co}^{2+}$ (Hamon et al., 1979). These authors concluded that the elevated $\mathrm{K}^{+}$levels were secondarily activating CaMK. A similar mechanism may rcgulate TPH activity in RN46A cells, as differentiation in $\mathrm{KCl}$ or $\mathrm{KCl} / \mathrm{BDNF}$ increased the number of moderate or high-intensity 5-HT immunoreactive cells between 1.5- and 2.6-fold, although these increases were not statistically significant. Both BDNF and elevated $\mathrm{K}^{+}$were required for maximal induction of 5-HT synthesis, and the temporal sequence of these treatments was crucial. BDNF treatment had to precede treatment with elevated $\mathrm{K}^{+}$. Collectively, these results indicate that independent mechanisms control the synthesis (BDNF) and activation (depolarization) of TPH in RN46A cells.

There is precedence for interactions of growth factors and depolarizing conditions in regulating neuronal survival and differentiation, although these interactions have proved to be distinct and cell-type specific. Depolarization increased vasoactive intestinal peptide (VIP) levels in adult sympathetic ganglion neurons grown in the presence of NGF (Sun ct al., 1992). In contrast, elevated $\mathrm{K}^{+}$blocked the induction of choline acetyltransferase, VIP, substance $P$, and somatostatin induced by CNTF in newborn sympathetic ganglion neurons (Rao et al., 1992). Lastly, in an immortalized sympathoadrenal progenitor cell line, partial depolarization induced trkA expression, allowing the cells to survive and differentiate in the presence of NGF (Birren et al., 1992). While these examples underscore the complexity of neurotrophic factor interactions with depolarizing conditions in vitro, they reflect similar regulatory events that occur in vivo (Kessler and Black, 1982; Hyatt-Sachs et al., 1993).

The RN46A cell line should prove to be a useful model of differentiating CNS neurons regarding delineating the molecular mechanisms that control neurofilament assembly and regulate 5-HT synthesis. Furthermore, temperature-sensitive neuronal cell lines have been shown to integrate into host parenchyma following transplantation into the adult (Onifer et al., 1993a,b) and neonatal (Renfranz et al., 1991) CNS. These neuronal cell lines are particularly amenable for transplantation studies because their immunological properties are such that once differentiated, they downregulate cell surface molecules necessary for recognition by cytotoxic T lymphocytes (White et al., 1994). Given a clear understanding of the mechanisms that underlie the neuronal differentiation of RN46A cells in vitro, these cells may ultimately prove useful to replace lost serotonergic neurons in vivo.

\section{References}

Azmitia EC, de Kloet ER (1987) ACTH neuropeptide stimulation of serotonergic neuronal maturation in tissue culture: modulation by hippocampal cells. In: Progress in brain research, Vol 72 (de Kloet ER, Wiegant VM, de Wied D, eds), pp 311-318. Amsterdam: Elsevier. Bartlett PF, Reid HH, Bailey KA, Bernard O (1988) Immortalization of mouse neural precursor cells by the c-myc oncogene. Proc Natl Acad Sci USA 85:3255-3259.
Bernard O, Reid HH, Bartlett PF (1992) Role of the c-myc and the $\mathrm{N}-m y c$ proto-oncogenes in the immortalization of neural precursors. J Neurosci Res 24:9-20.

Birren SJ, Verdi JM, Anderson DJ (1992) Membrane depolarization induces p140 irk and NGF responsiveness, but not p $75^{\text {LNGFR }}$, in MAH cells. Science 257:395-397.

Black MM, Lee VM-Y (1988) Phosphorylation of neurofilament proteins in intact neurons: demonstration of phosphorylation in cell bodies and axons. J Neurosci 8:3296-3305.

Blusztajn JK, Venturini A, Jackson DA, Lee HJ, Wainer BH (1992) Acetylcholine synthesis and release is enhanced by dibutyryl cyclic AMP in a neuronal cell line derived from mouse septum. J Neurosci 12:793-799.

Boadle-Biber MC (1979) Activation of tryptophan hydroxylase from slices of rat brain stem incubated with agents which promote calcium uptake or intraneuronal release. Biochem Pharmacol 28:2129-2138.

Boadle-Biber MC, Phan T-H (1986) AGN2979 [3-(3-methoxyphenyl)-3-(3-dimethylaminopropyl)-4,4-dimethylpeperidi-2,6-dione]: an inhibitor of the activation of tryptophan hydroxylase. Biochem Pharmacol 35:1521-1526.

Boadle-Biber MC, Phan T-H (1987) Involvement of calmodulin-dependent phosphorylation in the activation of brainstem tryptophan hydroxylase induced by depolarization of slices or other treatments that raise intracellular free calcium levels. Biochem Pharmacol 36: 1174-1176.

Bottenstein JE, Sato GH (1979) Growth of a rat neuroblastoma cell line in serum-free supplemented media. Proc Natl Acad Sci USA 76: 514-517.

Carden MJ, Trojanowski JQ, Schlaepfer WW, Lee VM-Y (1987) Twostage expression of neurofilament polypeptides during rat neurogenesis with early establishment of adult phosphorylation patterns. J Neurosci 7:3489-3504.

Casalbore P, Agostini E, Alema S, Falcone G, Tato F (1987) The $\mathrm{v}-m y c$ oncogene is sufficient to induce growth transformation of chick neuroretina cells. Nature 326:188-190.

Cashman NR, Durham HD, Blusztajn JK, Oda K, Tabira T, Shar IT, Dahrouge S, Antel JP (1992) Neuroblastoma X spinal cord (NSC) hybrid cell lines resemble developing motor neurons. Dev Dyn 194: 209-221.

Chao MV (1992) Neurotrophin receptors: a window into neuronal differentiation. Neuron 9:583-593.

Choi HK, Won LA, Kontur PJ, Hammond DN, Fox AP, Wainer BH, Hoffmann PC, Heller A (1991) Immortalization of embryonic mesencephalic dopaminergic neurons by somatic cell fusion. Brain Res 552:67-76.

Crawford GD Jr, Le W-D, Smith RG, Xie W-J, Stefani E, Appel SH (1992) A novel N18TG2 $\times$ mesencephalon cell hybrid expresses properties that suggest a dopaminergic cell line of substantia nigra origin. J Neurosci 12:3392-3398.

DeVitry F, Camier M, Czernichow P, Benda PH, Cohen P, Tixier-Vidal A (1974) Establishment of a clone of mouse hypothalamic neurosecretory cells synthesizing neurophysin and vasopressin. Proc Natl Acad Sci USA 71:3575-3579.

Dosemeci A, Pant HC (1992) Association of cyclic-AMP-dependent protein kinase with neurofilaments. Biochem J 282:477-481.

Ehret M, Cash CD, Hamon M, Maitre M (1989) Formal demonstration of the phosphorylation of rat brain tryptophan hydroxylase by $\mathrm{Ca}^{2+} /$ calmodulin-dependent protein kinase. J Neurochem 52:18861891.

Elder GA, Liang Z, Lee N, Friedrich V, Lazzarini RA (1992a) Novel DNA-binding proteins participate in the regulation of human neurofilament $\mathrm{H}$ gene expression. Mol Brain Res 15:83-96.

Elder GA, Liang Z, Snyder SE, Lazzarini RA (1992b) Multiple nuclear factors interact with the promoter of the human neurofilament $M$ gene. Mol Brain Res 15:99-107.

Evrard C, Borde I, Marin P, Galiana E, Prèmont F, Gros F, Rouget P (1990) Immortalization of bipotential and plastic glio-neuronal precursor cells. Proc Natl Acad Sci USA 87:3062-3066.

Frederiksen K, Jat PS, Valtz N, Levy D, McKay R (1988) Immortalization of precursor cells from the mammalian CNS. Neuron 1:439448.

Giordano M, Takashima H, Herranz A, Poltorak M, Geller HM, Marone M, Freed WJ (1993) Immortalized GABAergic cell lines derived from rat striatum using a temperature-sensitive allele of the SV40 large T antigen. Exp Neurol 124:395-400.

Globus MY, Wester P, Busto R, Dietrich WD (1992) Ischemia-in- 
duced extracellular release of serotonin plays a role in CA1 neuronal cell death in rats. Stroke 23:1595-1601.

Haltmeier H, Rohrer H (1990) Distinct and different effects of the oncogenes $c-m y c$ and $v-s r c$ on avian sympathetic neurons: retroviral transfer of $\mathrm{v}-m y c$ stimulates neuronal proliferation whereas $\mathrm{v}-s r c$ transfer enhances neuronal differentiation. J Cell Biol 110:2087-2098.

Hammang JP, Baetge EE, Behringer RR, Brinster RL, Palmiter RD, Messing A (1990) Immortalized retinal neurons derived from SV40 $\mathrm{T}$-antigen-induced tumors in transgenic mice. Neuron 4:775-782.

Hammond DN, Wainer BH, Tonsgard JH, Heller A (1986) Neuronal properties of clonal hybrid cell lines derived from central cholinergic neurons. Science 234:1237-1240.

Hamon M, Bourgoin S, Artaud F, Glowinski J (1979) The role of intraneuronal 5-HT and of tryptophan hydroxylase activation in the control of 5-HT synthesis in rat brain slices incubated in $\mathrm{K}^{+}$-enriched medium. J Neurochem 33:1031-1042.

Harris J, Ayyub C, Shaw G (1991) A molecular dissection of the carboxyterminal tails of the major neurofilament subunits NF-M and NF-H. J Neurosci Res 30:47-62.

Hemstead BL, Rabin SJ, Kaplan L, Reid S, Parada LF, Kaplan DR (1992) Overexpression of the trk tyrosine kinase rapidly accelerates nerve growth factor-induced differentiation. Neuron 9:1-20.

Hisanga S-i, Gonda Y, Inagaki M, Ikai A, Hirokawa N (1990) Effects of phosphorylation of the neurofilament $L$ protein on filamentous structures. Cell Regul 1:237-248.

Holets VR, Hökfelt T, Rokaeus A, Terenius L, Goldstein M (1988) Locus coeruleus neurons in the rat containing neuropeptide $Y$, tyrosine hydroxylase, or galanin and their efferent projections to the spinal cord, cerebral cortex, and hypothalamus. Neuroscience 24:893906.

Hyatt-Sachs H, Schreiber RC, Bennett TA, Zigmond RE (1993) Phenotypic plasticity in adult sympathetic ganglia in vivo: effects of deafferentation and axotomy on the expression of vasoactive intestinal peptide. J Neurosci 13:1642-1653.

Isobe T, Ichimura T, Sunaya T, Okuyama T, Takahashi N, Kuwano R, Takahashi Y (1991) Distinct forms of the protein-kinase dependent activator of tyrosine and tryptophan hydroxylases. J Mol Biol 217:125-132.

Kawamoto JC, Barrett JN (1986) Cryopreservation of primary neurons for tissue culture. Brain Res 384:84-93.

Kessler JA, Black IB (1982) Regulation of substance $P$ in adult sympathetic ganglia. Brain Res 234:182-187.

Largent BL, Sosnowski RG, Reed RR (1993) Directed expression of an oncogene to the olfactory neuronal lineage in transgenic mice. J Neurosci 13:300-312.

Lauder JM, Bloom FE (1974) Ontogeny of monoamine neurons in the locus coeruleus, raphe nuclei and substantia nigra of the rat. 1 . Cell differentiation. J Comp Neurol 155:469-481.

Lee HJ, Hammond DN, Large TH, Roback JD, Sim JA, Brown DA, Otten UH, Wainer BH (1990) Neuronal properties and trophic activities of immortalized hippocampal cells from embryonic and young adult mice. J Neurosci 10:1779-1787.

Martinez de la Escalera G, Choi AL, Weiner RI (1992a) Beta 1 -adrenergic regulation of the GT1 gonadotrophin-releasing hormone (GnRH) neuronal cell lines: stimulation of GnRH release via receptors positively coupled to adenylate cyclase. Endocrinology 131:13971402.

Martinez de la Escalera G, Gallo F, Choi AL, Weiner RI (1992b) Dopaminergic regulation of the GTl gonadotrophin-releasing hormone (GnRH) neuronal cell lines: stimulation of $\mathrm{GnRH}$ release via D1-receptors positively coupled to adenylate cyclase. Endocrinology 131:2965-2971.

Mellon PL, Windle JJ, Goldsmith PC, Padula CA, Roberts JL, Weiner RI (1990) Immortalization of hypothalamic GnRH neurons by genetically targeted tumorigenesis. Neuron 5:1-10.

Miller GM, Silverman A-J, Roberts JL, Dong KW, Gibson MJ (1993) Functional assessment of intrahypothalamic implants of immortalized gonadotropin-releasing hormone-secreting cells in female hypogonadal mice. Cell Transpl 2:251-257.

Nakamura Y, Takeda M, Angelides KJ, Tanaka T, Tada K, Nishimura $T$ (1990) Effect of phosphorylation of $68 \mathrm{kDa}$ neurofilament subunit protein assembly by the cyclic AMP dependent protein kinase. Biochem Biophys Res Commun 169:744-750.
Nixon RA, Shea TB (1992) Dynamics of neuronal intermediate filaments: a developmental perspective. Cell Motil Cytoskel 22:81-91.

Nixon RA, Sihag RK (1991) Neurofilament phosphorylation: a new look at regulation and function. Trends Neurosci 14:501-506.

Onifer SM, White LA, Whittemore SR, Holets VR (1993a) In vitro strategies for identifying transplanted primary CNS tissue and neuronal cell lines. Cell Transplant 2:131-149.

Onifer SM, Whittemore SR, Holets VR (1993b) Variable morphological differentiation of a raphe-derived neuronal cell line following transplantation into the adult rat CNS. Exp Neurol 122:130-142.

Patcher JS, Liem RKH (1984) The differential appearance of neurofilament triplet polypeptides in the developing rat optic nerve. Dev Biol 103:200-210.

Pessac B, Girard A, Romey G, Crisanti P, Lorinet AM, Calothy G (1983) A neuronal clone derived from a rous sarcoma virus-transformed quail embryo neuroretina established culture. Nature 302: 616-618.

Rao MS, Tyrrell S, Landis SC, Patterson PH (1992) Effects of ciliary neurotrophic factor (CNTF) and depolarization on neuropeptide expression in cultured sympathetic neurons. Dev Biol 150:281-293.

Ray J, Peterson DA, Schinstine M, Gage FH (1993) Proliferation, differentiation, and long-term culture of primary hippocampal neurons. Proc Natl Acad Sci USA 90:3602-3606.

Renfranz PJ, Cunningham MG, McKay RDG (1991) Region-specific differentiation of the hippocampal stem cell line HiB5 upon implantation into the developing mammalian brain. Cell 66:713-729.

Reynolds BA, Wciss S (1992) Generation of neurons and astrocytes from isolated cells of the adult mammalian central nervous system. Science 255:1707-1710.

Reynolds BA, Tetzlaff W, Weiss S (1992) A multipotent EGF-responsive striatal embryonic progenitor cell produces neurons and astrocytes. J Neurosci 12:4565-4574.

Ryder EF, Snyder EY, Cepko CL (1990) Establishment and characterization of multipotent neural cell lines using retrovirus vectormediated oncogene transfer. J Neurobiol 21:356-375.

Shaw G (1991) Neurofilament proteins. In: The neuronal cytoskeleton (Burgoyne R, ed), pp 185-214. New York: Wiley-Liss.

Shaw G, Weber K (1982) Differential expression of neurofilament triplet proteins in brain development. Nature 298:277-279.

Shaw G, Weber K (1983) The structure and development of the rat retina: an immunofluorescence microscopical study using antibodies specific for intermediate filament proteins. Eur J Cell Biol 30:219232.

Sihag RK, Nixon RA (1990) Phosphorylation of the aminoterminal head domain of the middle molecular mass $145-\mathrm{kDa}$ subunit of neurofilaments. J Biol Chem 265:4166-4171.

Sihag RK, Nixon RA (1991) Identification of Ser-55 as a major protein kinase A phosphorylation site on the $70-\mathrm{kDa}$ subunit of neurofilaments. J Biol Chem 266:18861-18867.

Sun Y, Rao MS, Landis SC, Zigmond RE (1992) Depolarization increases vasoactive intestinal peptide- and substance P-like immunoreactivities in cultured neonatal and adult sympathetic neurons. $J$ Neurosci 12:3717-3728.

Suri C, Fung BP, Tischler AS, Chikaraishi DM (1993) Catecholaminergic cell lines from the brain and adrenal glands of tyrosine hydroxylase-SV40 T antigen transgenic mice. J Neurosci 13:1280-1291.

Sweetnam PM, Sanon HR, White LA, Brass BJ, Jaye M, Whittemore SR (1991) Differential effects of acidic and basic fibroblast growth factors on spinal cord cholinergic, GABAergic, and glutamatergic neurons. J Neurochem 57:237-249.

White LA, Keane RW, Whittemore SR (1994) Differentiation of an immortalized CNS neuronal cell line decreases their susceptibility to cytotoxic T lymphocyte cell lysis in vitro. J Neuroimmunol 49:135143.

Whittemore SR, White LA (1993) Target regulation of neuronal differentiation in a temperature-sensitive cell line derived from medullary raphe. Brain Res 615:27-40.

Wood JN, Bevan SJ, Coote PR, Dunn PM, Harmar A, Hogan P, Latchman DS, Morrison C, Rougon G, Theveniau M, Wheatley S (1990) Novel cell lines display properties of nociceptive sensory neurons. Proc R Soc Lond [Biol] 241:187-194. 